\title{
APLIKASI TRICHODERMA UNTUK MENCEGAH PENYAKIT LAYU PADA TANAMAN CABAI ORGANIK DI DESA PERING KECAMATAN BLAHBATUH, KABUPATEN GIANYAR
}

\author{
B.R.T. Putri ${ }^{1}$, N.L.G. Sumardani ${ }^{1}$, I.D.P. Singarsa ${ }^{2}$ dan N.N. Yastini ${ }^{3}$
}

\begin{abstract}
ABSTRAK
Salah satu komoditas pertanian yang memiliki potensi pasar yang sangat baik adalah tanaman cabai, terutama cabai organik. Terdapat berbagai kendala dalam budidaya cabai organik seperti serangan hama, dan penyakit tanaman. Diantara sekian banyak jenis penyakit tanaman cabai, penyakit layu fusarium menjadi salah satu ancaman serius bagi petani, karena sangat mudah menular sehingga mengakibatkan penuruan produksi bahkan dapat mengakibatkan kegagalan panen. Layu fusarium disebabkan oleh cendawan patogen yaitu cendawan Fusarium oxysporum yang menyerang tanaman inang, sehingga mengakibatkan tanaman menjadi layu dan mati. Trichoderma $s p$ merupakan fungsida alami yang mampu melawan cendawan patogen. Pada tanggal 2 Juli 2018, telah dilakukan demplot aplikasi Trichoderma $s p$ pada tanaman cabai organik telah dilakukan di Desa Pering, Kecamatan Blahbatuh, Kabupaten Gianyar. Kegiatan diawali dengan penyuluhan tentang maanfaat dan cara kerja Trichoderma $s p$ untuk mencegah penyakit layu pada tanaman cabai, yang dilanjutkan dengan pelatihan pembuatan pupuk dasar, aplikasi Trichoderma sp, dan pendampingan. Hasil kegiatan ini menunjukkan bahwa aplikasi Trichoderma $s p$ pada demplot cabai organik di Desa Pering, Kecamatan Blahhbatuh, Kabupaten Gianyar telah berjalan dengan baik, dan mampu mencegah penyakit layu pada cabai.
\end{abstract}

Kata kunci : cabai organik, penyakit layu, fusarium oxysporum, trchoderma sp, desa pering

\begin{abstract}
Organic chilli, is ones of agricultural commodity that has a good market potential in Bali. There are various obstacles in organic chili farming such as pest attacks and plant diseases. Among the many types of chili diseases, fusarium wilt is one of the serious threats. Fusarium wilt is very contagious, cause a decrease in production, and even result in crop failure. Fusarium wilt is caused by pathogenic fungi, namely Fusarium oxysporum. It is attacks the host plant, causing wither and died plant. Trichoderma sp is a natural fungicide that is able to fight pathogenic fungi. On July $2^{\text {rd }}, 2018$, demonstration plot of application Trichoderma $s p$ on organic chili plants was carried out in Pering Village, Blahbatuh District, Gianyar Regency. The activity began with agriculture extension about the benefits of Trichoderma sp in preventing wilt disease in chili plants, followed by training to make fertilizer base, application of Trichoderma sp, and mentoring. The results of this activity indicate that the application of Trichoderma sp in organic chili demonstration plots in Pering Village, Blahhbatuh Subdistrict, Gianyar Regency has been going well, and is able to prevent wilting in chili.
\end{abstract}

Keywords: organic chili, wilt diseases fusarium oxysporum, trchoderma sp, pering village

\section{PENDAHULUAN}

Desa pering merupakan salah satu dari sembilan desa yang terdapat di Kecamatan Blahbatuh, Kabupaten Gianyar. Jumlah penduduk Desa Pering sebanyak 7938 jiwa tergabung dalam 1587 KK

\footnotetext{
${ }^{1}$ Dosen Fakultas Peternakan Universitas Udayana : tanamaputri@unud.ac.id

${ }^{2}$ Fakultas Pertanian Universitas Udayana

${ }^{3}$ Fakultas Pertanian Universitas Dwijendra Denpasar
} 
terdiri atas 3960 laki-laki dan 3969 perempuan, dengan mata pencaharian penduduk sebagian besar adalah bertani, diikuti oleh jasa perdagangan, peternakan, dan perikanan. Salah satu komoditas pertanian yang memiliki potensi pasar yang sangat baik adalah tanaman cabai, terutama cabai organik. Terdapat berbagai kendala dalam budidaya cabai organik seperti serangan hama, dan penyakit tanaman. Diantara sekian banyak jenis penyakit tanaman cabai, penyakit layu fusarium menjadi salah satu ancaman serius bagi petani, karena sangat mudah menular sehingga mengakibatkan penuruan produksi bahkan dapat mengakibatkan kegagalan panen (Santika,2006). Layu fusarium disebabkan oleh cendawan patogen yaitu cendawan Fusarium $s p$ yang menyerang tanaman inang, sehingga mengakibatkan tanaman menjadi layu dan mati (Semangun, 2007). Selama ini pada umumnya petani mengatasi penyakit layu pada cabai dengan penyeprotan menggunakan pestisida yang berdampak kurang baik bagi kualitas produksi dan lingkungan.

Berdasarkan permasalahan yang ada, maka perlu dicarikan suatu alternatif dalam mengatasi penyakit layu fusarium pada tanaman cabai organik. Salah satu metode yang dapat dilakukan untuk mencegah penyakit layu fusharium ini adalah aplikasi Trichoderma sp. Sifat antagonis Trichoderma $s p$ ini dapat dimanfaatkan sebagai alternatif dalam pengendalian cendawan patogen yang bersifat ramah lingkungan (Talanca,et al., 1998). Pernyataan ini didukung oleh Mukerji and Garg, 2006 yang menyatakan Trichoderma $s p$ merupakan fungsida alami yang mampu melawan cendawan patogen dan bersifat menguntungkan bagi tanaman.

Budidaya tanaman organik kini semakin berkembang dan popular di tengah masyarakat. Cara pertanian yang menghindar dari penggunaan bahan kimia ini memang menghasilkan hasil pertanian yang menyehatkan. Menurut Sardiana, dkk (2014) pertanian organik membawa banyak keuntungan seperti : memperbaiki kualitas tanah, mengurangi pencemaran kimia sintetis dari pestisida, dan menekan biaya produksi karena petani dapat memproduksi pupuk secara mandiri. Berdasarkan perimbangan tersebut, maka dalam pemberdayaan masyarakat petani cabe di Desa Pering dikembangkan sistem pertanian cabe organik.

\section{METODE PELAKSANAAN}

Berdasarkan permasalahan yang ada, maka metode yang diterapakan adalah:

1. Melakukan penyuluhan tentang aplikasi Trichoderma $s p$ pada pertanian cabai organik, dengan tahapan kegiatan sebagai berikut:

a. Memberikan penjelasan mengenai Trichoderma $s p$

b. Penjelasan mengenai bahan-bahan yang diperlukan

c. Penjelasan mengenai metode pencampuran Trichoderma sp dengan pupuk organik dan molases

d. Penjelasan mengenai cara kerja Trichoderma $s p$ dalam menyerang cendawan patogen Fusarium $s p$ penyebab penyakit layu pada cabai.

2. Mengadakan demoplot aplikasi Trichoderma sp untuk mecegah penyakit layu pada cabai organik.

3. Memberikan pendampingan dalam pertanian cabai organik dengan aplikasi Trichoderma $s p$.

\section{HASIL DAN PEMBAHASAN}

Kegiatan demplot penanaman cabai organik dengan aplikasi Trichoderma sp untuk mencegah penyakit layu pada cabai diawali dengan sosialisasi dan koordinasi pelaksanaan program kepada pihak Pemerintah Daerah dan OPD (Organisasi Pelaksana Daerah) terkait. Sosialisasi dilaksanakan pada tanggal 4 April 2018 bertempat di kantor Bappeda Kabupaten Gianyar. Tujuan kegiatan sosialisasi ini adalah untuk menyampaikan program kegiatan yang akan dilaksanakan kepada pihak 
Pemerintah Kabupaten Gianyar yang kemudian dapat disinkronisasikan tentang program dan waktu yang ada pada OPD terkait. Sosialisasi ini berjalan lancar dan mendapat tanggapan yang baik dari Pemerintah Kabupaten Gianyar.

Selanjutnya pada tanggal 16 Mei 2018 dilakukan survei menentukan lokasi demplot. Berdasarkan hasil survei dan wawancara dengan beberapa kelompok masyarakat, maka ditentukan Banjar Tojan Desa Pering sebagai lokasi tempat pelaksanaan demplot.

Persiapan demplot cabai organik dengan aplikasi Trichoderma sp diawali dengan kegiatan penyuluhan tentang cara kerja Trichoderma sp dalam mencegah penyakit layu pada tanaman cabai yang dilaksanakan pada tanggal 2 Juli 2018. Materi yang disampaikan pada kegiatan penyuluhan adalah memberikan penjelasan mengenai cara kerja Trichoderma $s p$ dalam mengatasi penyakit layu fusharium pada cabai (Gambar 1). Trichoderma merupakan genus cendawan yang mampu dijadikan sebagai agen pengendali patogen secara hayati. Mekanisme antagonis yang dilakukan Trichoderma $s p$ dalam menghambat pertumbuhan patogen antara lain kompetisi, parasitisme, antibiosis, dan lisis (Purwantisari,2009). Mekanisme antagonis Trichoderma sp terhadap cendawan patogen dilakukan dengan mengeluarkan toksin berupa enzim $\beta-1,3$ glukanase, kitinase, dan selulase yang dapat menghambat pertumbuhan dan bahkan membunuh cendawan patogen (Talanca, et al., 1998).

Kegiatan penyuluhan ini dilanjutkan dengan melakukan aplikasi secara langsung dengan menyiapkan lahan tanam seluas 5 are di Desa Tojan, Desa Pering. Kegiatan diawali dengan penggemburan tanah, lalu dibiarkan selama kurang lebih 1 minggu untuk menghilangkan racun tanah. Selanjutnya dilakukan pemasangan bedengan pada lahan dengan ukuran kurang lebih 1 meter, tinggi $30 \mathrm{~cm}$ dengan panjang disesuaikan dengan panjang lahan. Antar bedengan satu dengan bedengan yang lainnya diberikan jarak kurang lebih $30 \mathrm{~cm}$ (Gambar 1). Jarak antar bedengan ini berfungsi sebagai jalan bagi petani dalam memudahkan aktifitas penanaman dan pemanenan, selain itu jarak ini juga dapat berfungsi sebagai parit disaat musim hujan.

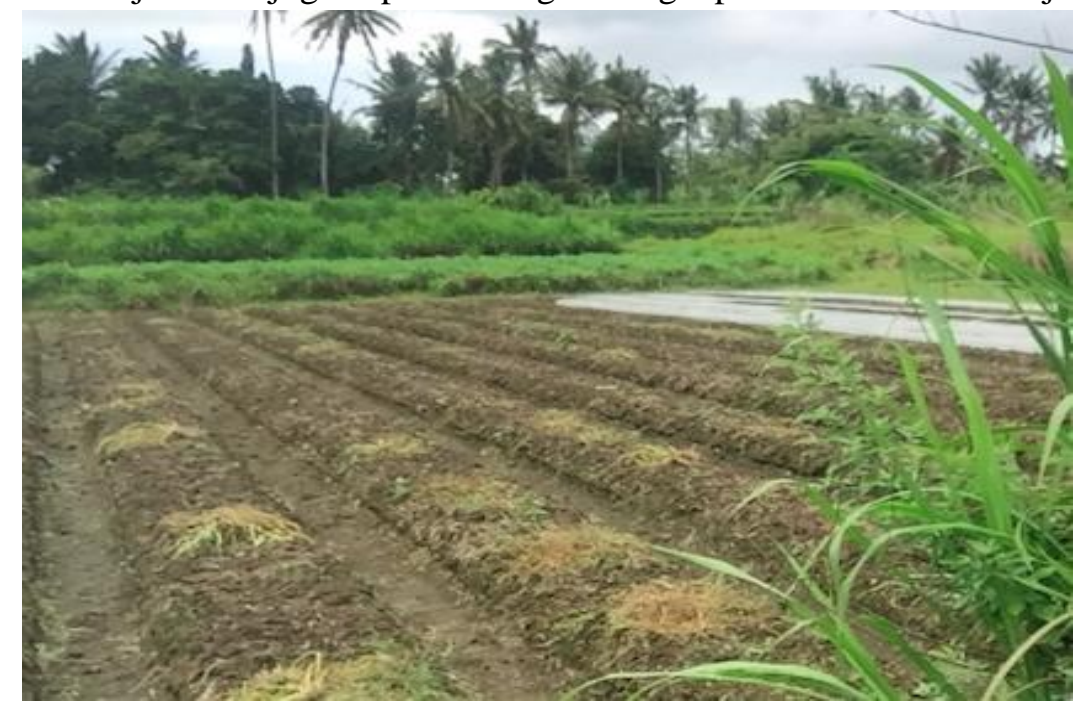

Gambar 1. Persiapan Lahan untuk Penanaman Cabai Organik

Pupuk organik yang telah dicampurkan dengan Trichoderma sp kemudian dimasukkan kedalam lubang tanam (Gambar 2). Penanaman cabai dilakukan lima hari setelah pemberian pupuk dengan tujuan Trichoderma $s p$ yang diaplikasikan telah tumbuh dan berkembang dengan baik. 
Aplikasi Trichoderma untuk Mencegah Penyakit Layu pada Tanaman Cabai Organik di Desa Pering, Kecamatan Blahbatuh, Kabupaten Gianyar

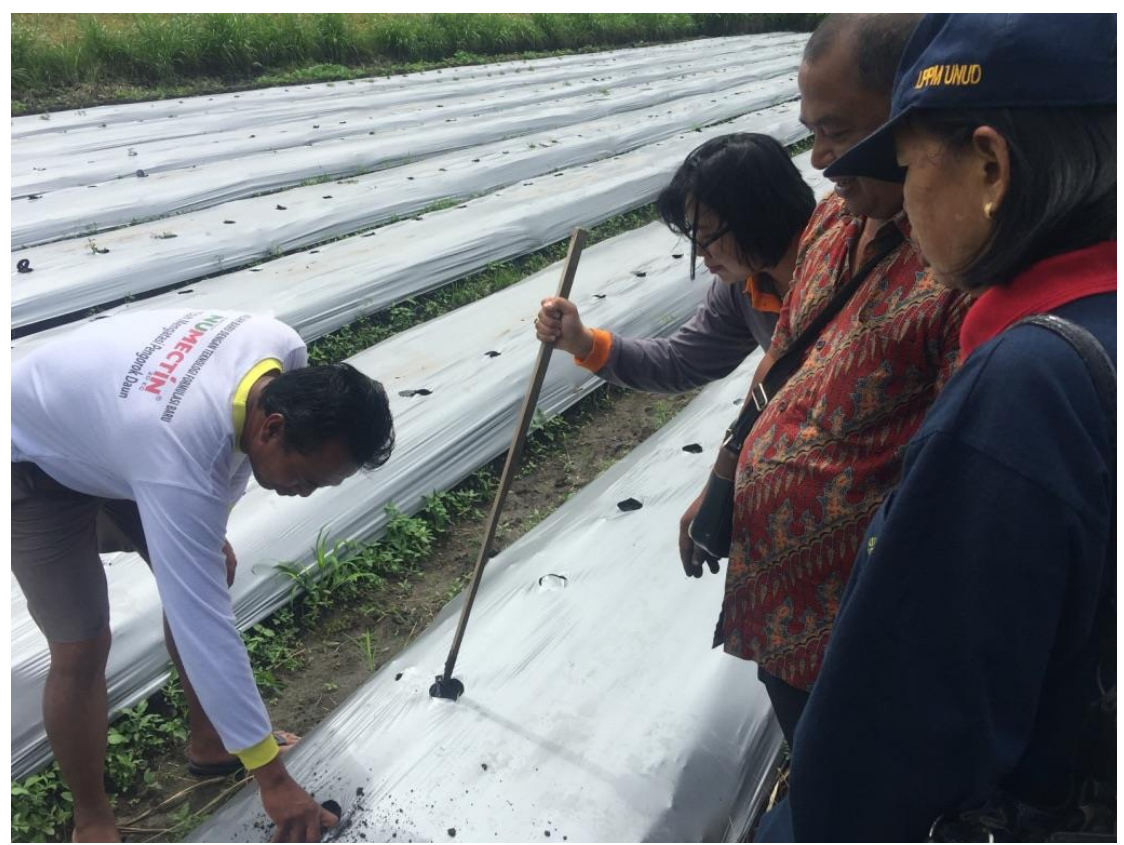

Gambar 2. Pemberian Pupuk Organik yang Telah Diberi Aplikasi Trichoderma sp

Kegiatan pendampingan dilakukan secara intensif antara tim pelaksana kegiatan dengan petani, baik dari segi sharing informasi teknis mengenai tata cara penananaman cabai organik dengan aplikasi Trichoderma sp, maupun solusi tentang penanganan berbagai masalah yang dihadapi.

Pertumbuhan cabai yang ditanam pada demplot ini sangat baik, tanaman cabai tumbuh subur tanpa gangguan penyakit (Gambar 4). Masyarakat sangat antusias dengan hasil demplot ini, dan ingin segera mengaplikasikannya.
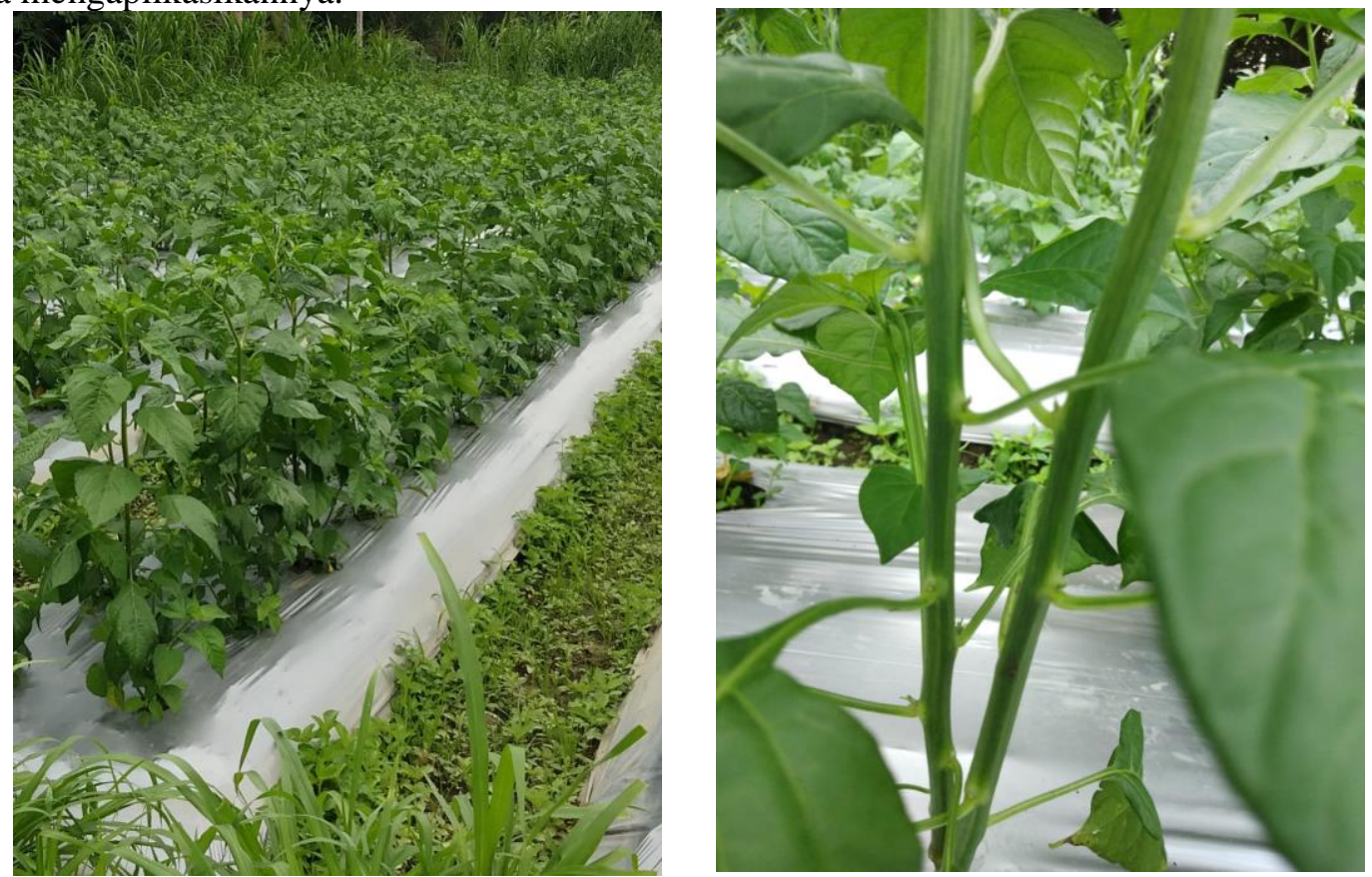

Gambar 4. Cabai Organik Tumbuh dengan Baik dan Sehat 


\section{SIMPULAN DAN SARAN}

\section{Simpulan}

Dari hasil kegiatan yang telah dilakukan dapat disimpulkan bahwa kegiatan pengabdian kepada masyarakat yang dilakukan telah berjalan dengan baik. Intensitas komunikasi antara pelaksana kegiatan dengan petani cukup tinggi untuk mendiskusikan tentang aplikasi Trichoderma sp, serta mekanisme kerjanya dalam menyerang cendawan patogen penyebab penyakit layu fusarium pada tanaman cabai.

\section{Saran}

Kegiatan pengabdian kepada msyarakat kali ini masih terfokus pada kegiatan on farm. Diharapkan untuk kegiatan-kegiatan selanjutnya, dapat merambah pada sektor hilir yaitu kegiatan pemasarannya sehingga pendapatan petani dapat terus ditingkatkan.

\section{UCAPAN TERIMAKASIH}

Ucapan terimakasih kami sampaikan kepada: Direktorat Jenderal Riset dan Pengembangan Kementerian Riset, Teknologi, dan Pendidikan Tinggi Republik Indonesia yang telah mendanai kegiatan pengabdian kepada masyarakat ini.

\section{DAFTAR PUSTAKA}

Mukerji, K.G and K.L. Garg, 2006. Biocontrol of plant Disease. CRC Press Inc. Boca, Florida. Purwantisari S. 2009. Isolasi dan identifikasi cendawan indigenous rhizosfer tanaman kentang dari lahan pertanian kentang organik di Desa Pakis. Magelang. Jurnal BIOMA. ISSN: 11 (2): 45.

Santika Adhi, 2006. Agribisnis Cabai. Swadaya. Jakarta.

Sardiana, I.K., I.M. Adnyana, I.B.P. Manuaba and I.G.A.M S Agung. 2014. Soil Organic Carbon, Labile Carbon and Organic Carbon Storage under Organic and Conventional Systems of Chinese Cabbage in Baturiti, Bali Indonesia. Journal of Biology, Agriculture and Healthcare. Vol. 4. No. 21. Pp. 63-71

Semangun, H, 2007. Penyakit-Penyakit Tanaman Holtikultura Indonesia, Gadjah Mada University Press, Yogyakarta.

Talanca, AH, Soenartiningsih, dan Wakman,W. 1998. Daya Hambat Jamur Trichoderma sp. pada Beberapa Jenis Jamur Patogen. Risalah Seminar Ilmiah dan Pertemuan Tahunan XI PEI, PFI, dan HPTI, Sulawesi Selatan, Maros. 